\title{
BEYOND THE IMAGERY: THE ENCOUNTERS OF KIERKEGAARD AND DOSTOEVSKY WITH THE IMAGE OF THE DEAD CHRIST*
}

\begin{abstract}
:
Through an analysis of Kierkegaard's and Dostoevsky's approaches to the theme of the death of Christ - one of the major leitmotifs in the debate of their contemporaries conveyed through theological and philosophical considerations, but also expressed in novels and in art - I show how the thinkers comprehended and articulated in their works the religious challenges awaiting the modern man.
\end{abstract}

\section{KEY WORDS:}

Kierkegaard, Dostoyevsky, Mimesis, Ekphrasis, Holbein, Crucifixion; Religious Aesthetics, Modernity.

Søren Aabye Kierkegaard and Fyodor Mikhailovich Dostoevsky are two figures who never met, who were shaped by different experiences and who came from completely dissimilar environments, but who share similar ideas, intuitions and understandings of their worlds. The former, a self-published preacher of integrity, unrecognized and misunderstood by his contemporaries, ended his life in bitterness and financial bankruptcy. The latter, a wellpublished gambler, author of great renown, appreciated and listened to, lived a fairly good life through his writing. Kierkegaard, a traveler of the imagination, enclosed by the dense streets of Copenhagen, and Dostoyevsky, a frequent passenger of international trains and coaches running across Russia, Prussia, the Lands of Partitioned Poland, and Switzerland, were both thinkers who eyewitnessed, understood and articulated the social change that came as a result of the revolutions of the nineteenth century and the production of the modern man, which in turn reflected the crisis of culture, political orders and the Christian religion. The main discourses of the age where shaped by the clash between the apologists of the great systems of Kant and Hegel, and the Romantics. The intellectual dispute between the former group - defenders of conservative values - and the latter - advocates of absolutely free individual produced on the one hand disinterested and self-complacent bourgeoisie, and on the other absolute relativists and nihilists. Theology and philosophy, but al-

\footnotetext{
* I would like to acknowledge my deep appreciation for Jessica Louise Trevitt's (a PhD student at Monash University, Melbourne) linguistic corrections.
} 
so literature and art reflected the change in religious discourses and expressed the new challenges that were awaiting not only the status of religious institutions but also the faith of particular individuals. Growing textual criticism and historical studies started undermining the credibility of Scriptures as a reliable foundation for culture.

Through an analysis of Kierkegaard's and Dostoevsky's approaches to the theme of the death of Christ - one of the major leitmotifs in the debate of their contemporaries conveyed through theological and philosophical considerations, but also expressed in novels and in art - I show how the thinkers comprehended and articulated in their works the religious challenges awaiting the modern man. In this exposition I concentrate on particular works of the thinkers that account for their exemplary engagements with the theme of the dead Christ. An image of the crucified Christ from Kierkegaard's pseudonymous Does a Human Being Have the Right to Let Himself Be Put to Death for the Truth? ${ }^{1}$ and Practice in Christianity, ${ }^{2}$ and Dostoevsky's use of Holbein's Dead Christ in his novel The Idiot ${ }^{3}$ will here serve as what I call the image of the dead Christ.

First, I show that Kierkegaard and Dostoevsky apply in their writings the image of the dead Christ as a structural device and a method used to redefine Christianity in the wake of modernity. For Kierkegaard and Dostoevsky an individual identifies their religious status in relation to what stands for the extreme and paradoxical of the Christian faith: the image of the dead Christ. In the former thinker's thought this finds its expression in an admirer-follower distinction. The latter author introduces a methodology of redefining the individual's relation to Christianity by presenting Muishkin's, Rogojin's, and Hippolyte's relationship to the image of the dead Christ.

Second, I present the thinkers' engagement with the image of the dead Christ as a response to modern aesthetics. Kierkegaard and Dostoevsky challenge the imagery and aesthetic confines of the picture by pointing beyond the immediate experience of the reader-viewer. Although the aesthetic experience cannot substitute the religious experience, both authors appeal to an aesthetic means of ekphrasis to allow the religious idea to interact with the viewerreader.

Lastly, analyzing Kierkegaard's and Dostoevsky's employment of the image of the dead Christ in their writings, I point to how the authors define the human condition of their contemporaries. I show that the thinkers attempt through their works to challenge the way people think about Christianity. In order to properly diagnose the condition of the age, the thinkers introduce

1. Søren Kierkegaard, "Does a Human Being Have the Right to Let Himself Be Put to Death for the Truth?," Without Authority, H. and E. Hong ed., trans. (Princeton, NJ: Princeton Univ. Press, 1997), p. 49-90.

2. Søren Kierkegaard, Practice in Christianity, H. and E. Hong, ed., trans. (Princeton, NJ: Princeton Univ. Press, 1991).

3. Fyodor M. Dostoevsky, The Idiot, Eva M. Martin, trans. (London: Heron Books, 1968). 
measures of paradoxical models of the Christian ideal, that is a guerilla-martyr for Kierkegaard and an idiot for Dostoevsky.

\section{Redifining Christianity}

Kierkegaard's writings of 1848 onwards are marked by his constant references to the death of Christ. The thinker links this subject to his task of "redefining Christianity" in the wake of modernity. His pseudonymous Practice in Christianity deals with presenting a genuine definition of a Christian. The work finds a resolution to the problem in a fundamental distinction between an admirer of Christ and a follower of Christ. The admirer approaches Christ in a disinterested way. ${ }^{4}$ The admirer merely admires Christ for his work of atonement and redemption. The admirer in thankfulness and appreciation objectively appropriates the narrative of sin, incarnation and redemption. In selfcomplacence the admirer chooses the right religion, hoping it will fix the whole mess called "evil" and bring him a cozy spot in a vaguelycomprehended heaven.

The genuine Christian however is someone with a different approach to Christ than the admirer. ${ }^{5}$ A Christian is someone who in his religious approach breaks through the mere admiration of Christ and, disregarding the centuries of established Christianity, becomes what Kierkegaard calls "contemporary with Christ." As contemporary with Christ, a Christian starts to follow their master just like the disciples did centuries ago. To become a Christ-follower one has to face the 'offence' that comprises the paradox of God-man and the horror of the death of Christ.

Practice in Christianity published in 1850 by Kierkegaard's pseudonym Anti-Climacus has been accompanied by another of his pseudonymous works written by H.H., Does a Human Being Have the Right to Let Himself Be Put to Death for the Truth? This was published a year earlier, but was written almost simultaneously with the former. The former work, written in the style of the meditational lectio divina of devotio moderna, has been purposefully founded in the latter, a more aggressive and violent work. ${ }^{6}$ The notion of martyrdom as the inevitable destiny of a true Christian as expressed in Practice in Christianity has been already phrased in the eponymous question of the work Does a Human Being Have the Right to Let Himself Be Put to Death for the Truth? the essay that was to serve as a guerilla to the later published work of Anti-

4. Brian Gregor, "Thinking Through Kierkegaard's Anti-Climacus: Art, Imagination, And Imitation," Hey J L, 50, no. 3 (2009): 448, 453.

5. George Pattison, Kierkegaard's Upbuilding Discourses: Philosophy, Literature, and Theology (London and New York: Routledge 2013), p. 158.

6. For more on Kierkegaard's relations to such devotional literature see: Christopher B. Barnett, "'Should One Suffer Death for the Truth?': Kierkegaard, Erbauungsliteratur, and the Imitation of Christ," Journal for the History of Modern Theology, 15 (2008): 232-47; Christopher B. Barnett, Kierkegaard, Pietism and Holiness (Farnham: Ashgate, 2011); Joel D. S. Rasmussen, Between Irony and Witness: Kierkegaard's Poetics of Faith, Hope, and Love (New York and London: T\&T Clark, 2005). 
Climacus. ${ }^{7}$ Reading these works in the intended order, the reader stumbles on the somehow intense and extreme, and almost, on the first impression, awkwardly positioned image of horror: "the picture of the Crucified One." This dreadful picture bothers, torments, and haunts the main characters of the above-mentioned pseudonymous works, and, as will be shown later in this essay, is to torment the reader as well.

Less than a quarter of a century later and almost twelve years after Kierkegaard's collapse on one of the streets of Copenhagen that shortly preceded his death, Fyodor Dostoevsky finds himself disturbed and moved by Hans Holbein's painting Dead Christ (Der Leichnam Christi im Grabe, 1521). ${ }^{8}$ The painting, which presents the mutilated body of Christ taken down from the cross, executes such a powerful impression on the Russian thinker that, bewildered by it, he utters: "One could lose his faith from a painting like that." 9 The consequences of Dostoevsky's encounter with the picture of horror are even greater. Shortly after seeing it in Kunstmuseum Basel, Dostoevsky incorporates its copy into his novel The Idiot, of which the action takes place mainly in St. Petersburg. Some scholars believe that the novel as a whole is orchestrated around the theme of Holbein's picture and that the picture itself works as a key to The Idiot. ${ }^{10}$ While this thesis seems somewhat radical, the work of Holbein is in fact one of the main themes of Dostoyevsky's novel. The thought expressed by the Russian thinker upon seeing Dead Christ, which is then repeated by the main character of the book Prince Muishkin, indirectly articulates Kierkegaard's thought that the image of the dead Christ distinguishes someone who does have faith from someone who does not.

Both Kierkegaard and Dostoevsky introduce the image of the dead Christ as a reference point in their vision of redefining Christianity in the wake of modernity. The modern man must face the paradox of the Christian faith in all its brutality and without any softening disguise that would make it easier to accept its requirements. In Kierkegaard's works we can see this articulated in a story of a man who was brought up contemplating Christ as he is portrayed in sacrificial manners. In the Introduction to H.H.'s essay we read:

"Once upon a time there was a man. As a child he had been strictly brought up in the Christian religion. He had not heard much of what children ordinarily hear about the little baby Jesus, about angels and the like. On the other hand, the Crucified One had been all the more frequently depicted to him; therefore his picture was the one and only impression he had of the Savior. Although a child, he was already like an old man. This picture followed him

7. Andrew Burgess, "Kierkegaard, Moravian Missions, and Martyrdom," in Robert L. Perkins, ed., Without Authority, The International Kierkegaard Commentary, vol. 18 (Macon: Mercer Univ. Press, 1985), p. 184.

8. Joseph Frank, Dostoevsky: A Writer in His Time (Princeton, NJ: Princeton Univ. Press, 2009), pp. 549-50;

9. K. A. Lantz, The Dostoevsky Encyclopedia (Westport: Greenwood Publishing Group, 2004), p. 189

10. Sarah J. Young, "Holbein's Christ in the Tomb in the Structure of The Idiot," Russian Studies in Literature, 44, no. 1 (2007): 90-102. 
throughout his life; he never became young again, and he never lost sight of this picture." 11

"In this way he secretly attended to this picture; he never spoke of it to anyone. But the picture steadily came closer and closer to him, and he felt its claim on him even more deeply." 12

The man from the essay tested his faith toward the vision of Christ sacrificed, and the picture of "the Crucified One" was for him the only (true) vision of Christ. For Kierkegaard, the image of the dead Christ represents the core of Christianity and in this he opposes his contemporary apologists of the Christian faith. ${ }^{13}$ Modern textual criticism restricted the Gospels to a narrative deprived of supernatural elements. Theologians and philosophers of Kierkegaard's age tried to concentrate on what the Dane calls the triumphant church - a phenomenon that perceived the Christian religion as a part of process of development of history across the ages. ${ }^{14}$ The truth of Christianity was "scientifically" guaranteed by fitting in with the Hegelian historicity and his theory of development and succession of ideas. Kierkegaard criticized that concept, showing that Christianity does not need any defense. According to him, only those who secretly do not believe in the truths of Christian religion undertake various types of apologetics. The truth of Christianity is its weakness, its vulnerability, and its paradox. To be a genuine Christian one as a single individual has to face the Christ despised and violated in all its horror. Christianity and its truth is therefore a matter of either 'the offense' or faith.

Dostoevsky seems to be giving a similar appraisal. The three main characters of The Idiot - Muishkin, Rogojin, and Hippolyte - define themselves in their relation to the image of the dead Christ. Over the door of one of the rooms in Rogojin's house hangs a copy of Holbein's picture, the original of which Muishkin saw in Switzerland. The picture ignites a brief religious dialogue between Muishkin and Rogojin and works as a digression in their argument about the femme fatale of St. Petersburg, Nastasia Philipovna. Rogojin asks Muishkin whether he is a Christian. Muishkin's response echoes Dostoyevsky's famous reaction uttered upon seeking the picture in Basel: "One could lose his faith from a painting like that." ${ }^{\text {"I5 }}$ Muishkin's reply is indirect and dialectic. On the hand, he is resolved and silent about his position of being a Christian. On the other hand, he fails to communicate his faith in conversa-

11. Kierkegaard, Without Authority, p. 55.

12. Ibid., p. 55-56.

13. Søren Kierkegaard, Søren Kierkegaard's Journals and Papers, H. and E. Hong, ed., transl. (Bloomington and London: Indiana Univ. Press, 1967), 4: 3862; Søren Kierkegaard, The Sickness Unto Death, H. and E. Hong, ed., trans. (Princeton, NJ: Princeton Univ. Press, 1980), p. 87. ". . . he who first invented the notion of defending Christianity in Christendom is de facto Judas No. 2. ..."

14. Anders Holm, "The Church," The Oxford Handbook of Kierkegaard, John Lippitt and George Pattison, ed. (Oxford: Oxford Univ. Press, 2013), p. 122; Erik Hanson, "Thomas Merton: Kierkegaard, Merton and Authenticity," Kierkegaard's Influence on Theology, Jon Stewart ed. (Aldershot: Ashgate, 2012), pp. 120-22.

15. Dostoevsky, The Idiot, p. 207. "That picture! That picture!" "Why, a man's faith might be ruined by looking at that picture!" 
tion with Rogojin at that moment, just as he failed to articulate it in a conversation with Rogojin when they met as strangers in a train. This failure of Muishkin reappears throughout the book. His deep infatuation with Christ's death resembles the man from Kierkegaard's works as discussed above. Muishkin, in a similar manner to that man from H.H.'s essay, is resolved and silent. However, as we progress through the book, we see that the Prince's position may be entirely related to his mental imbalance and lack of sanity. Muishkin does not reveal in a direct way that he is a Christian. "Echoing" the Christian from Practice in Christianity, he communicates his Christianity indirectly, by reduplicating in his life what he held as true. ${ }^{16}$ Further on in the text, Colia and Hippolyte indirectly confirm Muishkin's Christianity.

Rogojin relates to the image of the dead Christ differently. On the one hand he is full of passion. Dostoevsky testifies to a strange mood that Rogojin falls into shortly after seeing the picture. Muishkin also brings our attention to it when he notices involuntarily Rogojin's "strange way of speaking and looking." ${ }^{17}$ On the other hand, Rogojin disregards the power of the image of the dead Christ, summarizing his relation to it with a mere "I like looking at that picture." 18 It seems that Rogojin situates himself as among the "many people [who] are unbelievers nowadays, especially Russians, [as] I have been told. You ought to know - you've lived abroad."19 Rogojin expresses in his position towards the picture a certain ambivalence of disinterestedness mixed with fury.

An interesting interpretation contributed by one scholar of Rogojin's contemplation of Holbein's painting observes that "Rogozhin likes to look at Holbein's painting because it confirms his fear that Christ is not divine, but mortal, and seems to deny the doctrine of His Resurrection and the consequent redemption of mankind." ${ }^{20}$ This could explain some of Rogojin's behaviors like his attempt to "acquire" Nastasia by borrowing 100,000 rubles, his exchange of his gold cross for a tin cross, his failed murder of Muishkin and his successful murder of Nastasia. This line of thinking fits with the famous dictum that has been molded from the words of Mitya Karamazov: "Without God...Everything is permissible." ${ }^{21}$

Hippolyte Terentieff's My Necessary Explanation is a classic example of an early nihilist's perception of the essence of Christianity contained in the image of the dead Christ. This is how the young intellectual perceives Holbein's picture:

16. Kierkegaard, Practice in Christianity, pp. 133-34.

17. Dostoevsky, The Idiot, p. 207.

18. Ibid

19. Ibid.

20. Jeffrey Meyers, Painting and the Novel (Manchester: Manchester Univ. Press, 1975), p. 140

21. Fyodor Dostoevsky, Brothers Karamazov, Richard Pevear and Larissa Volokhonsky, transl. (New York: Farrar, Straus, and Giroux, 1990), p. 589. 
There was nothing artistic about it, but the picture made me feel uncomfortable. It represented Christ just taken down from the cross. It seems to me that painters as a rule represent the Saviour, both on the cross and taken down from it, with great beauty still upon His face. This marvelous beauty they strive to preserve even in His moments of deepest agony and passion. But there was no such beauty in Rogojin's picture. This was the presentment of a poor mangled body which had evidently suffered unbearable anguish even before its crucifixion, full of wounds and bruises, marks of the violence of soldiers and people, and of the bitterness of the moment He had fallen with the cross - all this combined with the anguish of the actual crucifixion. ${ }^{22}$

Following that thought, Hippolyte asks himself the crucial question of how those who saw this distressing corpse - the apostles, and the women who eyewitnessed this cruel tragedy - could believe that such a mutilated body would be resurrected. Hippolyte does not find in himself faith enough to believe. On the one hand, Hippolyte, following Kierkegaard's terminology, is an admirer, but not a believer. On the other hand, his admiration for Christ is ethicalreligious. He admires Christ, but believes that Christ's death - and his own death as he himself is on the verge of passing away - is the very end of his existence. For Hippolyte the image of the dead Christ expresses "[t]his blind, dumb, implacable, eternal, unreasoning force . . . and the absolute subordination of all men and things to it." ${ }^{23}$ Hippolyte, in a similar manner to Christ, awaits in "fear and uncertainty" 24 the terror of nothingness to come. This Dostoevskian honesty of uncertainty from Hippolyte seems to complete the image of Muishkin as a Christian model - a theme that I undertake in the last part of my essay.

\section{The limits of aesthetics}

So far I have discussed some theological and religious aspects of Kierkegaard's and Dostoevsky's engagements with the image of the dead Christ. We showed that the thinkers used the image of the dead Christ as a device to redefine Christianity in the context of modernity. However, the works of Kierkegaard and Dostoevsky, apart from discussing various theological or religious matters, have had a deep influence on other fields. In this part of my essay, I

22. Dostoevsky, The Idiot, p. 391.

23. Ibid., p. 392.

24. Krzysztof Michalski, The Flame of Eternity. An Interpretation of Nietzsche's Thought (Princeton, NJ: Princeton Univ. Press, 2012), pp. 80-81. "But what is supposed to mean that Christ dies in fear and uncertainty? How is it possible that God is terrified? What could 'God's Anxiety' possibly mean?. . . What is Christ afraid of?. . . Let's take a moment to consider this fear, the fear of nothingness. . . When I say that, fearing death, I am afraid of nothingness, I mean the end, disintegration, the annihilation of everything I know and can imagine, of all the flies, feelings, equations, concepts, obligations, and everything else that one can call 'something.' The prospect of death places this 'nothing' - the edge of all possible knowledge and, by the same token, of the person in me, the person I know, the person who sees, feels, runs, and knows - before our very eyes. It is the end of my world." 
show that Kierkegaard and Dostoevsky through the image of the dead Christ engage in the discussion regarding the status of modern aesthetics.

Kierkegaard's main concern in the matter is exhibited by his identifying the ambitions of aesthetics in taking the place of religion. The Danish thinker perceives aesthetic experience attempting to substitute itself for religious experience. ${ }^{25}$ For Kierkegaard, art can only give the reader-viewer-listener the immediate sense of their experience and the reflection that springs out of the immediate experience is always something different to the experience itself. Any reflection on the immediate experience is through mediation: the aesthetic is therefore limited. It cannot communicate the religious for fear it will poeticize it. But to poeticize the religious is to alienate subjectivity from real life. "The religious person seeks to live in life what the poet expresses in art." 26 The religious has to be lived out, it has to be experienced; reflection does not precede the truly religious and therefore it does not mediate the religious experience.

The other dimension of Kierkegaard's ideas on the limits of aesthetics is that in aesthetic experience the one who experiences does not go beyond his own creative self. Following the Romantic understating of aesthetics, the experience of the reader-observer-listener is not completely determined by the idea or by the way the idea is incorporated or encapsulated in the art piece, but rather by the capacity of their creative ' $\mathrm{I} \cdot{ }^{27} \mathrm{In}$ consequence, the readerobserver-listener in the very act of experiencing accesses merely his own immediate and disinterested reaction to the appropriated object; the experience is thus of the immanent. The aesthetic experience therefore is unable to reach the transcendent.

What is then the aesthetic status of the image of the dead Christ if we consider that it is still a kind of image? The Romantic ideal of an art piece was to capture in itself the ideal relation between the world of the Idea/Thought and the material world (and then express it) in the ideal form. ${ }^{28}$ Such an art piece reveals in itself the optimal relation between form and content and therefore allows the reader-observer-listener to "participate" in the eternal/timeless of the Idea. For Kierkegaard the picture of "the Crucified One" from Does a Human Being Have the Right to Let Himself Be Put to Death for the Truth? is a picture that has different qualities to a piece of art that aims at expressing the Idea. In short, the image of the dead Christ exceeds its merely aesthetic dimension and works as a sign that points beyond itself. Its aesthetic dimension demonstrates by negating and obliterating the aesthetic qualities that which an

25. In this article, and here in particular, my understanding of aesthetics (and the aesthetic) in Kierkegaard and his rendering of aesthetic experience try to follow the appraisal presented in George Pattison, "Kierkegaard: Aesthetics and 'the Aesthetic,'” British Journal of Aesthetics, 31, no. 2 (1991): 140-51.

26. George Pattison, "Kierkegaard as Novelist," Journal of Literature and Theology, 1, no. 2 (1987): 219.

27. Frederick Burwick, Mimesis and its Romantic Reflections (University Park: Pennsylvania State Univ. Press, 2001), pp. 77-106.

28. Pattison, "Kierkegaard: Aesthetics and 'the Aesthetic,'" p. 141. 
aesthetic object would strive for in its ideal. The picture of "the Crucified One" is a dynamic image. It follows its observer, acquires power over him, requires something of him, comes closer and closer to him; the man never loses sight of the picture, cannot look away, and he is driven by an inexplicable power to want to resemble the picture. ${ }^{29}$ The picture of "the Crucified One" interacts with its observer. Kierkegaard's pseudonymous author H.H. circumscribed the aesthetic qualities of the picture: "He [the man] had always considered it ungodly that one would undertake to paint this picture and equally ungodly to look artistically at such a painted picture to see if it resembled him (the Crucified One) - instead of becoming oneself the picture that resembled him. ..."30

A similar critique of aesthetics can be found in Dostoevsky's The Idiot. Beauty is one of the main subjects of the work. Although "[i]n The Idiot, many kinds of beauty are mentioned: female, artistic, ethical and religious," 31 it seems that Dostoyevsky overall presents a negative assessment of beauty in the book. The most appealing of Dostoevsky's expressions of the disenchantment with beauty can be found in the already quoted Hippolyte's My Necessary Explanation, where the young nihilist comments on the copy of Holbein's picture in Rogojin's house. Hippolyte notices, "It seems to me that painters as a rule represent the Saviour...with great beauty still upon His face." ${ }^{32}$ This however is pointless, as the image of the dead Christ is a presentation of a mutilated body and a representation of an unanimated corpse has no beauty in itself. Yet it is not the lack of beauty or the manifestation of ugliness that makes the sensitive and honest Hippolyte reject Christianity: the ugliness of the image allows the observer to be offended, disturbed, irritated, and finally awakened from the self-complacent satisfaction of the bourgeois religion of good taste and manners. Therefore, it is the offence embedded in the image of the dead Christ that claims that such an ugly corpse came back to life.

Drawing on the above-presented ideal of Romantic art - which aims at representing the Idea in a tangible form, for example the beauty of the world one sees that in Hippolyte's eyes Holbein's picture gives an account of the world as a dark and hostile place that "crushed and swallowed up a great and invaluable Being." 33 The young nihilist asks: "Can there be an appearance of that which has no form?" 34 And he answers, "And yet it seemed to me, at certain moments, that I beheld in some strange and impossible form, that dark, dumb, irresistibly powerful, eternal force." ${ }^{35}$ The insight gained by looking at the image of the dead Christ encapsulates the nature that is a "dumb mon-

29. Kierkegaard, Without Authority, pp. 55-57.

30. Ibid., p. 55.

31. Wil van den Bercken, Christian Fiction and Religious Realism in the Novels of Dostoevsky (London: Anthem Press, 2011), p. 107.

32. Dostoevsky, The Idiot, p. 391.

33. Ibid., p. 392.

34. Ibid.

35. Ibid. 
ster." ${ }^{36}$ Contrary to the Romantics, Dostoevsky through Hippolyte insists that art does not allow the reader-viewer-listener access to the timeless/eternal of the Idea that reveals itself in and through the world; Holbein's picture demonstrates that, in brief, Nature does not care about anything, including the Idea, unless the Idea is an "embodiment" of "terror and dread." 37

The authors' criticisms of the modern aesthetics, however, do not prohibit them from appealing to aesthetic devices. Although for Kierkegaard aesthetic experience cannot be substituted for religious experience, and the aesthetic of beauty eventually brings disillusion for Dostoevsky, both thinkers implement an aesthetic means of ekphrasis in their work. Ekphrasis is an aesthetic device that was initially related to how objects exist and are presented. ${ }^{38}$ The classic example of ekphrasis is Homer's description of the Shield of Achilles in Book 18 of the Iliad, which is a literary account of a work of visual art. ${ }^{39}$ Scholars tend to trace the philosophical dimensions of ekphrasis to its occurrence in Plato's Republic. In that work Socrates claims that a painter represents not what already exists in nature but its imitative representation; therefore the painter is "at the third removed from the essential nature of the thing...third in the succession from the throne of truth." ${ }^{40}$ Ekphrasis is understood here as artistic representation (in painting or sculpture) of objects that are already representations of some reality; art understood as the fine art imitates the art of craftsmen whose work comprise of an imitation of the true reality. Plato criticizes that kind of imitation, and his critique is consistent with his understanding of the role of art in society, including textual (or rhetorical) representations of objects of art. How is ekphrasis understood in relation to Kierkegaard's engagement with an image? Across the history of literature, art, and philosophy the classic rendering of ekphrasis as a mainly rhetorical device evolves and expands. Among the modern considerations of ekphrasis, the dominant discussion focuses on the issue of verbal representation of what has already been represented visually and vice versa. The issue of whether a verbal illustration can represent - that is, make present - its object in the same way as can a visual representation provokes questions related to another dimension of ekphrasis, that of representation in any medium which is non-representable or which enhances the original idea in a multitude of ekphrastic actions. In fact these kinds of questions were strongly present among the authors Kierkegaard either read or heard about.

One of the first endeavors to systematically face those issues can be found in Lessing's rendering of ekphrasis in his Laocoon - a work broadly discussed among the Romantics and known to Kierkegaard, who referred to it in his Ei-

36. Ibid.

37. Ibid

38. On ekphrasis see: Simon Goldhill, "What is Ekphrasis for?," in Classical Philology, 102 (2007): 1-19.

39. James A. H. Heffernan, Museum of Words: The Poetics of Ekphrasis from Homer to Ashbery (Chicago: Univ. of Chicago Press, 2004), pp. 9-22.

40. Plato, Republic, p. 597e. 
ther/Or. ${ }^{41}$ As the subtitle of the work suggests - An essay upon the limits of painting and poetry - Lessing discusses the difference between poetic production (art with words) and visual production (art with physical objects). Taking into account the structures of both mediums, Lessing embarks on an analysis of the representational and communicational capacities of poetry and painting. His considerations are expressed in the discussion of the relation between the portrayals of the mythical figure of Laokoon in Virgil's Aeneid and the sculpture of Laocoon by an unknown artist. According to Lessing, both poetry and painting are independent, and moreover, both of them can depict certain qualities that the other cannot. ${ }^{42}$ Out of that discussion comes one of Lessing's central ideas: poetry has a superior relation to paining as its application is more extensive and it can represent realms that painting cannot. ${ }^{43}$ According to Lessing, painting can only represent a moment, but poetry has the ability to represent certain continuity and in consequence can encompass a larger scope of what is being represented. ${ }^{44}$ The role of art is to give a representation of beauty; art does not aim at particular imitative representations of beautiful objects. ${ }^{45}$ Poetry has the ability to represent a larger spectrum of qualities of that which it makes present, but, what is even more important, poetry appeals to the receiver with greater strength (as poetry is armed with all those qualities painting lacks) and makes the viewer's experience more complex.

What is important here is Lessing's understanding of ekphrasis as a device or even a literary genre that aims at representing in mediums of art the Idea, and his elevation of beauty as the category that has a decisive role in judging given representations. Art aims at representing the beautiful, but its role does not end there. "[I]n [Lessing's] view readers and audiences are involved in the production process. . . . He regards the recipients of artworks as necessary for the work to be completed in the sense of an inner re-creation of the poetic world." ${ }^{46}$ The audience receives art in space and time but not at the same time - these dimensions characterize painting and poetry respectively. "The world produced in literature is essentially temporal: the author's time merges by way of the work with the reader's time; the space of the painter and the sculptor is the space of the observer." ${ }^{\prime 47}$ Although temporality characterizes the realm of words and sounds - it takes time to think, to write and to read what is written - a particular understanding of time characterizes the way the art of paining is appropriated: that is, in the moment.

How does Lessing's understanding of mimesis and ekphrasis work in relation to Kierkegaard? It seems that Kierkegaard, although immensely inspired

41. Søren Kierkegaard, Either/Or 1, H. and E. Hong, ed., trans. (Princeton, NJ: Princeton Univ. Press, 1987), p. 169.

42. Gotthold E. Lessing, Laocoon. Or the Limits of Poetry and Painting, Ellen Frothingham, trans. (Boston: Roberts Brothers, 1887), pp. 91-92.

43. Gunter Gebauer, Christoph Wulf, Mimesis. Culture. Art. Society (Berkeley: Univ. of California Press, 1992), pp. 186-95.

44. Ibid.

45. Burwick, Mimesis and its Romantic Reflections, pp. 112-13.

46. Gebauer, Wulf, Mimesis, pp. 188-89.

47. Ibid., p. 192. 
by Lessing's rendering of aesthetics, gives an alternative understanding of mimesis and ekphrasis, especially in his multifaceted understanding of image and its role in his philosophy. ${ }^{48}$ Kierkegaard addresses Lessing in two ways. First, in his pseudonymous Either/Or Kierkegaard directly demonstrates the limits of both visual and verbal arts through his inability to represent the truly Christian quality of humility. Humility's representation requires the presentation of the "continuous coming into existence."49 Following that, the author notices that "art...portrayed Christ as the image of patience" $" 50$ but he claims that this portrayal misses the point as Christ should be portrayed not in patience, but in suffering. Alas, "long-suffering cannot be portrayed artistically, for the point of it is incommensurable with art; neither can it be poetized, for it requires the protraction of time. ${ }^{" 51}$ Kierkegaard's image embodied in the image of the crucified Christ is opposed to Lessing's rendering of aesthetics. What Kierkegaard presents almost represents anti-aesthetics in relation to Lessing's rendering. The image of the crucified Christ is ugly - conversely to Lessing's understanding that the role of aesthetics is to represent what is beautiful - and it represents violence and chaos - conversely to Lessing's idea that art should represent harmony.

Second, Kierkegaard's different approach to mimesis and ekphrasis can be seen in a cooperative and synergic understanding of various mediums of art, contrary to Lessing bringing to the fore one particular type of art over another. The image of the dead Christ - conversely to Lessing's rendering of the limit and capacity of art to represent the idea and to his differentiation of one art over another - is not reserved to one particular medium, but is structurally consist across various mediums. Consequently, the image of the dead Christ is Kierkegaard's alternative to Lessing's critique of ekphrasis, because it is understood as the synergy and cooperation of various mediums of art within the work; the image of the crucified Christ is in fact, on the one hand, a spoken picture, and on the other hand, a visualized narrative. Kierkegaard's rendering of ekphrasis concentrates on the effects the image has on the receiver. Although the image of the dead Christ is a picture, it does not have just one moment of appropriation - contrary to how Lessing sees the role of a picture -

48. Although the extent of Kierkegaard's inspiration taken from Lessing is a subject of ongoing discussion, it is certain that the Dane knew the writings of Lessing well enough to both directly and indirectly refer to the thinker in his considerations. Such methodology of indirect references to a thinker without acknowledging the thinker by Kierkegaard is an inherent part of his literary style. In my brief comparison of the philosophers I take this methodology into account, emphasizing structural and thematic relations between the content of their writings, which illuminate links between their renderings of aesthetics.

49. Kierkegaard, Either/Or 1, p. 135. "Humility is hard to portray precisely because it is sequence, and whereas the observer needs to see pride only at its climax, in the second case he really needs to see something that poetry and art cannot provide, to see its continuous coming into existence, for it is essential to humility to come into existence continuously, and if this is shown to him in its ideal moment, he misses something, for he senses that its true ideality consists not in its being ideal at the moment but in its being continuous."

50. Ibid., p. 136

51. Ibid. 
but it is being constantly re-appropriated and re-understood by the receiver throughout his life. This kind of image, in its synergy with a spoken narrative, has its effect spread over time. We will see a similar methodology in Dostoevsky's understanding of the confines of the image.

In his critique of Lessing's theory of aesthetics, Kierkegaard does not merely disregard Lessing's idea. On the contrary, ${ }^{52}$ Kierkegaard incorporates into his image of the crucified Christ Lessing's theory of the recipient's role in the process of production of the image.$^{53}$ According to Lessing, the receiver of an aesthetic production has to recreate in his own world the message conveyed in the artwork. ${ }^{54}$

This notion of Lessing's theory is strongly present in the thought of Kierkegaard and one could identify its twofold manifestation. On one level we see this idea occurring in Kierkegaard's concept of the martyr portrayed over the course of his late writings, according to which a reader becomes a martyr (Kierkegaard himself as a reader of his own writings is of no exception here he appropriates the idea into his own life and becomes a sort of a martyr himself $^{55}$ ). On another level, however, we read that "the picture of the Crucified One" creates another picture by the virtue of reproduction through resembling - by staring at the picture of the Crucified Christ, the child is "becoming...the picture that resembled him." the child, in the process of comprehending the picture of the crucified Christ, ultimately embarks on representing in its own self the sufferings of Christ. The child grows to be a man who seeks the answer to the eponymous question of the essay - the essay that outlines the narrative space of its existence Does a Human Being Have the Right to Let Himself be Put to Death for the Truth?

Contrary to Kierkegaard, who does not refer to any particular physical representation of the image of the dead Christ in his discourse (although one familiar with the pietistic background of Kierkegaard would be aware of the kind of art Kierkegaard has in mind $^{57}$ ), Dostoevsky introduces a piece of art that can be easily identified. Prince Muishkin in fact recognizes the painting in

52. As indicated in footnote 48, Kierkegaard draws upon Lessing extensively. An example from another pseudonymous work of Kierkegaard The Concept of Anxiety shows that the Dane incorporates into his concept of aesthetics Lessing's belief that the medium of the word allows the communicated message to be conveyed in time. On the other hand Kierkegaard disagrees with Lessing, insisting that the moment - the sudden - is important to break from the timelessness of art. Religiously speaking the moment is the instance of kairotic time; aesthetically speaking the moment is a pure abstraction. See: Søren Kierkegaard, The Concept of Anxiety, H. and E. Hong, ed., trans. (Princeton, NJ: Princeton Univ. Press, 1980), p. 132. "The words and the speaking, no matter how short when regarded in abstracto, always have a certain continuity for the reason that they are heard in time. But the sudden is a complete abstraction from continuity, from the past and from the future."

53. Gebauer, Wulf, Mimesis, p. 188

54. Ibid.

55. Joakim Garff, Søren Kierkegaard. A Biography, Bruce H. Kirmmse, trans. (Princeton, NJ: Princeton Univ. Press, 2000), pp. 626-36, 732-92; See also footnote 65.

56. Kierkegaard, Without Authority, p. 55.

57. See: Barnett, Kierkegaard, Pietism and Holiness, pp. 47-57. 
the book. The Russian novelist engages with ekphrasis in The Idiot in a similar manner to Kierkegaard, by addressing its synergic function that interrelates the visual of the image of the dead Christ with its spoken re-representation in the text. In fact "of the twenty-six or so biblical allusions in the novel, the majority concern the Crucifixion, followed by Apocalypse." 58 Dostoevsky renders the image of the dead Christ across the novel and situates it in key moments of the plot, thus spreading the image of the dead Christ over both time and space. By engaging Muishkin, Rogojin, and Hippolyte with the image of the dead Christ, Dostoevsky allows the reader to approach the image in several modes. Although the three figures consider the image of the dead Christ differently, they are univocal in indicating the silence of the broken human body. All the apocalyptic visions painted by Lebedeff are nonsensical and pointless if we permit Holbein's painting to speak for itself. Christ is dead...God is dead: this is the "anti-Gospel" of the modern times in all its brutality and plainness. Appealing to ekphrasis, "Dostoevsky strives to transcend the limits of his genre, which requires telling rather than showing. The result is a profound tension between...word and image. The two work together; the image can bear meaning only in profoundly human silence, molchanie, that great release that comes when the struggle with words finally subsides." ${ }^{, 59}$ The silence is present not only in Christ's inability to speak for himself, but also in the taciturnity that follows Hippolyte's speech, that is Muishkin's inability to say anything to save the Christian faith. It is also present in the absence of Resurrection in the biblical narrative that is woven into the text and the tragic events that end the novel. ${ }^{60}$

Although it is most likely that Dostoevsky never read Lessing's works, we can still find in his presentation of the image of the dead Christ an invitation directed towards the reader to face the death of God and to "experience" the drama of the image of the dead Christ. The above-mentioned silence that follows the image of the dead Christ "guarantees" the reader's freedom through her recreation of the image in her own personal world. What is also true of other works of the Russian novelist, and what we are reminded of especially when reading him alongside Kierkegaard's concept of indirect communication, is that the "readers of Dostoevsky...are not merely spectators at a tragedy, no matter how powerful the emotional catharsis such an experience may offer.", 61

\section{Reintroducing the Christian ideal}

58. Diane Oenning Thompson, "Problems of the Biblical Word in Dostoevsky's Poetics," Dostoevsky and the Christian Tradition, ed. George Pattison, Dianne Oenning Thompson (Cambridge: Cambridge Univ. Press, 2001), p. 73

59. Carol Apollonio Flath, Dostoevsky's Secrets: Reading against the Grain (Evanston, IL: Northwestern Univ. Press, 2009), pp. 166-67.

60. For a different appraisal presenting that the lack of an explicitly-mentioned resurrection indicates its inherent hidden presence, see: Flath, Dostoevsky's Secrets: Reading Against the Grain, pp. 96-98.

61. George Pattison, "Reading Kierkegaard and Dostoevsky Together," Dostoevsky and the Christian Tradition, p. 251. 
So far I have argued that Kierkegaard's and Dostoevsky's engagements with the image of the dead Christ are deliberately implemented first to redefine Christianity and second to challenge some dominant renderings of aesthetics. In this final part of my essay, following what has already been stated, I show that the thinkers render the image of the dead Christ as a means of recontextualizing and reintroducing Christianity. To challenge the way modern people understand Christianity, Kierkegaard and Dostoevsky initiate new models of the Christian ideal that confront the standards established in their societies. As we will shortly see, the thinkers usually portray these models as figures marked by a certain type of "degradation and suffering" -features that are "to be seen as a mode of the incognito of Christ." 62

Kierkegaard's categories of the aesthete and the ethical represent the way the thinker structures his anthropology on the one hand, and how he sees his society on the other. Hegelianism and, opposing the movement, the thought of the Romantics represented by thinkers like Friedrich von Schlegel, Ludwig Tieck and Karl Wilhelm Ferdinand Solger - permeated intellectual discourses of Kierkegaard's contemporaries. ${ }^{63}$ The Romantics believed that the creative 'I' of the extraordinary has no limits and that a genius is more than merely someone with talent. In art they sought the real medium and a representation of the highest there is in a human being. In their thinking, the Romantics criticized a society that threatened the particularity of an individual; they believed that the social order is in fact an artificial construction that suppresses the uniqueness of a particular person. The Romantics believed that they are not inescapably rooted in the rigidness of any religious-social-political institution and that they can create themselves without referring to those contingent constructs. Their critique, which was an all-out war on the established order, found opponents in the philosophy of Hegel and Hegelians.

The followers of Hegel perceived the established order to be a natural consequence of the logically-developing Idea. Hegelianism reinforced structures of religion, society and politics, showing that each of these are part of a larger picture, that is an historically-driven process. According to Kierkegaard, the philosophy of Hegel, by situating a single individual only as a meaningless part of a larger entity, devaluated the meaning of that individual. Neither group in their bilateral criticism grasped the merit of Christianity according to Kierkegaard, and in consequence reduced it to something either completely irrelevant and oppressive or temporary and provisional.

The Romantics engrossed in sensuality and egoism on the one hand, and disoriented in the spiritual cul-de-sac of melancholy and nihilism on the other, represent Kierkegaard's aesthete. Their opponents, immersed in selfcomplacency, career, and the business of the bourgeois life, resonate with

62. George Pattison, Anxious Angels. A retrospective View of Religious Existentialism (Basingstoke: St. Martin's Press, 1999), p. 61. "For Dostoevsky as for Kierkegaard degradation and suffering come to be seen as a mode of the incognito of Christ, although for more graphically portrayed than in Kierkegaard."

63. Jon Stewart, Kierkegaard's Relation to Hegel Reconsidered (Cambridge: Cambridge Univ. Press. 2007), pp. 170-81, 622-52. 
Kierkegaard's concept of the ethical. ${ }^{64}$ However, for Kierkegaard it is neither the sensual nor the commonsensical that represent what it is to be a Christian. The genuine Christian is the one who risks his life for truth (in contrast with both the aesthete who contests any concept of truth, or the ethical who is not willing to risk anything) and the one who will lose it for this cause: the martyr. ${ }^{65}$

The child from Kierkegaard's pseudonymous work reduplicates in his own life the answer to the eponymous question of the essay Does a Human Being Have the Right to Let Himself Be Put to Death for the Truth?, and thus he becomes a martyr. The child goes through a process of mental preparation to become a martyr, an undertaking which resonates with another title of an already-mentioned pseudonymous work of Kierkegaard, Practice to Christianity. An alternative translation of this title is also illuminating because it changes the word "practice" for "training." ${ }^{\text {"66 }}$ Both translations profoundly represent the meditational aspect of these works, as they are rooted in the devotional literature of dovotio moderna, but they also exceed its contemplative dimension, illuminating the very practical and physical aspect of the undertaking. In fact, the author of Does a Human Being Have the Right to Let Himself Be Put to Death for the Truth? is dead. The essay is a posthumous work. His attack on established Christianity comprises his written work and his death, which corresponds with this work. The martyr is a guerrilla or a terrorist because he undertakes his attack "from behind" and "without authority". He fires his "guns" and "awaits" a spiritual awakening. The martyr-guerrilla is therefore a model of the true Christian and consequently, as shown above, it represents the picture of the dead Christ by ultimately "becoming...the picture that resembled him" in the extreme. ${ }^{67}$

Dostoevsky's model of the Christian ideal is different from the one presented by Kierkegaard, but no less controversial. It is the inherent quality of

64. Still however, Kierkegaard calls the bourgeois life "the aesthetic" to accentuate the life that "fails to live up to its ethical potential." See Pattison, "Kierkegaard: Aesthetics and "the Aesthetic,'" pp. 140, 148.

65. Kierkegaard, Søren Kierkegaard's Journals and Papers, 1: 481. "Being a Christian is neither more nor less, without a doubt neither more nor less, than being a martyr; every Christian, that is, every true Christian, is a martyr;" 3: 2649. "Then the tyrant dies, and his rule is over; the martyr dies, and his rule begins. The tyrant was the egotistic individual who inhumanly ruled over the masses, made the others into a mass and ruled over the mass. The martyr is the suffering single individual who in his love of mankind educates others in Christianity, converting the mass into single individuals. . . Whole volumes could be written about this alone, even by me, a kind of poet and philosopher, to say nothing of the one who is coming, the philosopher-poet or the poet-philosopher, who, in addition, will have seen close at hand the object of my presentiments at a distance, will have seen accomplished what I only dimly imagine will be carried out sometime in a distant future." See Wojciech Kaftánski, "Mimesis in Does a Human Being Have the Right to Let Himself Be Put to Death for the Truth? Remarks on the Formation of the Self, Kierkegaard Studies Yearbook (2011), pp. 195-219.

66. Søren Kierkegaard, Training in Christianity: And the Edifying Discourse Which “Accompanied" It, Walter Lowrie, trans. (Oxford: Oxford Univ. Press, 1941).

67. Kierkegaard, Without Authority, p. 55. 
paradox that fundamentally marks the Christian models in the writings of both thinkers. Dostoevsky in The Idiot depicts the Christian ideal in the figure of Prince Muishkin ${ }^{68}$ and this protagonist, in his various encounters with the characters of the book, reveals the condition of Russian society. Muishkin suffers from idiocy mixed with epilepsy. ${ }^{69}$ His long-term treatment in Switzerland does not bring significant positive results and he comes back to his homeland as a poor invalid without prospects. Simply through his naivety and simplicity Muishkin becomes entangled in a series of complex events in St. Petersburg. His short existence in the modern city makes him acquainted with persons from various states of society. Muishkin finds himself involved in a sagacious and deceitful game between former aristocrats, emerging bourgeoisie, nihilist intellectuals and "commonplace people." ${ }^{\text {"70 }} \mathrm{He}$ is being taken advantage of by all of them, but the consequences of their actions often turn against their intentions. It is through him and in him that others can understand their true motives, and can measure the authenticity of their Christianity. Right at the beginning of the book the reader is informed that the protagonist does not respond with a sense of natural suspicion to impertinence and inappropriateness. ${ }^{71}$ Interrogated in a train carriage he unreservedly talks about his

68. The matter of whether Muishkin is a Christian model is debatable. In favour of this opinion is the inter alia appraisal presented by Liza Knapp, "Myshkin through a Murky Glass, Guessingly," Dostoevsky's The Idiot: A Critical Companion, Liza Knapp, ed. (Evanston, IL: Northwestern Univ. Press, 1998), pp. 191-217. Some scholars either disagree with perceiving Muishkin as a Christian model or claim that Muishkin is a failed model, see Thompson, "Problems of the Biblical Word in Dostoevsky's Poetics," pp. 75-76, or see Muishkin as a tragic figure: Sarah J. Young, Dostoevsky's The Idiot and the Ethical Foundations of Narrative: Reading, Narrating, Scripting (London: Anthem Press, 2004), pp. $75-$ 135. For a general overview of the problem, see Sarah J. Young "Introduction" to Dostoevsky's The Idiot and the Ethical Foundations of Narrative, especially, pp. 1-10 and Harriet Murav, Holy Foolishness: Dostoevsky's Novels \& the Poetics of Cultural Critique (Stanford: Stanford Univ. Press, 1992), pp. 74-75.

69. Although I am positioning Muishkin as a Christian ideal in this essay, I believe also, as I have suggested already in the first part of this analysis, that Hippolyte serves as a Christian model for Dostoevsky in The Idiot. It seems that both characters represent two sides of the Christian ideal. They share certain physical illnesses (idiocy/epilepsy and tuberculosis), both receive a certain revelation in their attacks of fits (Muishkin) and delirium (Hippolyte). In his My Necessary Explanation, Hippolyte reformulates Muishkin's concerns about the devastating influence of the image of the dead Christ. Muishkin represent the selfless goodness of Christian ideal and Hippolyte accounts for the existential experience while facing the absolute of the unknown. Julia Kristeva, although she situates Hippolyte as a minor character in The Idiot, she agrees that he is "the narrator's and Myshkin's double." See Julia Kristeva, The Black Sun, Leon S. Roudiez, trans. (New York: Columbia Univ. Press, 1992), p. 107.

70. Dostoevsky's term. Dostoevsky, The Idiot, p. 443. "There are certain people of whom it is difficult to say anything which will at once throw them into relief - in other words, describe them graphically in their typical characteristics. These are they who are generally known as 'commonplace people,' and this class comprises, of course, the immense majority of mankind. Authors, as a rule, attempt to select and portray types rarely met with in their entirety, but these types are nevertheless more real than real life itself."

71. Dostoevsky, The Idiot, p. 2. "He seemed to have no suspicion of any impertinence or inappropriateness in the fact of such questions being put to him." 
lack of mental health, lack of money, lack of any abode in the place he was going to, and lack of any concrete plans for the near future. Both of his fellow travelers Rogojin and Lebedeff make fun of the protagonist. But this is merely the beginning of a stream of ridicule and mockery that will be part of Muishkin's experience in St. Petersburg. He continues to be an object of amusement for the Epanchins family to whom he is distantly related. His naivety, selfless devotion and "otherworld approach to life" 72 make the majority of characters of the novel feel drawn to him, but on the other hand Muishkin's qualities repel them. Muishkin's condition also discloses his interlocutors as conflicted individuals. People address him in a conflicted manner: Nastasia Philipovna and Aglaya Epanchin both love the man in various ways, but when they find out that his pure love would make them prone to taking advantage of him, they ultimately refuse him.

The Christian ideal embedded in the figure of Muishkin serves as a fulcrum for the author's analysis of the condition of the Russian society of the city. ${ }^{73}$ The depicted people of St. Petersburg - the city that has dramatically and fundamentally changed since Muishkin's last stay - are bored, capricious, whimsical, opportunistic, and calculative. Muishkin in contrast is deficient of shrewdness, craftiness, the ability to plot strategies, and "reflection." He is different and his difference is marked, as he clearly emphasizes, by his mental and physical condition. In the age of modernity it is the idiot that retains the "true humane" and represents a true Christian.

This conception can be grasped through the situation of Nastasia Philipovna whose "case" is among the main affairs of the book. It is in her that the desires of almost all the characters of the book culminate. Nastasia is being objectified by participants of a socially-established rivalry, and her true good is scarcely the concern of the ongoing affairs. Muishkin is the only one who shows her compassion. He cannot marry Nastasia because he is an invalidhe is not driven by various overpowering passions like those who try to take financial, sexual or social advantage of her. All he has for her and for others is simply "unreflected" and unmediated love. Muishkin perceives Nastasia as a victim and as a lost soul engrossed in despair. His perspective seems to be in agreement with that of the narrator who strengthens Muishkin's intuition by presenting her former keeper Totsky in a pejorative light. Dostoevsky's description of Totsky, who greatly contributes to Nastasia's misery and mental imbalance, both reinforces Muishkin's perception of Nastasia and betrays the author's criticism of the self-complacent bourgeoisie: "his position was solid and respectable; his place in society had long been firmly fixed upon safe foundations; he loved himself, his personal comforts, and his position better than all the world, as every respectable gentleman should!" 74 Totsky's diagnosis of Nastasia is that she is insatiable, but it seems that it is he who suffers from financial and social insatiability. Another description of the city people

72. Richard Curle, Introduction, in Dostoevsky, The Idiot, p. ix.

73. George Pattison, Kierkegaard, Religion and the Nineteenth Crisis of Culture (Cambridge: Cambridge Univ. Press, 2004), pp. 204-10.

74. Dostoyevsky, The Idiot, p. 40. 
can be found in Dostoevsky's description of the Epanchins immersed in celebrating typical bourgeoisie rituals like elaborate dinners, teas, coffees, readings, instrument playing, etc. Muishkin in contrast does not follow the social standards and often misses the courtesy protocol, unveiling its artificiality and pitifulness.

Muishkin's holy idiocy is compared with Lebedeff's buffoonery. The former claims he has "lived less than other people" 75 and therefore he knows less of life. The latter knows more than a regular inhabitant of a city. Although he is able to formulate prophetic visions of the inhuman and apocalyptic technologization of the emerging modern era, his wise thoughts mix with his opportunistic knowledge about the whereabouts of those he simultaneously admires and despises. His criticism of industrialization and the development of railroads does not stop him from desiring the wealth of those who made money in that business. Muishkin's lack of knowledge protects him from the effect of the emerging civilization of technology; he does not know much, but he retains the inner goodness and authenticity. ${ }^{76}$

Lastly, Muishkin's religious exceptionality expresses itself in the fact that he receives religious insights through and in his illness. His spasmatic fits are the foundation of his religious experience. He is contrasted with Rogojin who although coming from pious Old Believers kills Nastasia out of passion. In fact Muishkin himself at the beginning of the book is prophesying the murder, when he answers Gania's question as to whether Rogojin could merry Nastasia: "Why not? Certainly he would, I should think. He would marry her tomorrow! - marry her tomorrow and murder her in a week! ${ }^{17}$

\section{Conclusion}

It comes as no surprise to find that reading Kierkegaard alongside Dostoevsky is beneficial. This essay has drawn upon the intuition that these two thinkers share a similar understanding of the time and space they inhabit. Kierkegaard and Dostoevsky are great observers and their examinations and analysis of the modern man are still valid even in our times. In this article I have tried to show how the thinkers understood and articulated the crisis of nineteenthcentury culture and religion. I have also attempted to present the way in which the thinkers perceived the social changes in their societies as marked by the emergence of the new individual but also of the new class of bourgeoisie.

I have drawn upon the way in which Kierkegaard and Dostoevsky related to the discussion on aesthetics, showing that the image of the dead Christ challenges the naïve and shallow ideas of beauty as the highest expression of form. I have also shown that the thinkers perceived aesthetics as limited in their representation of the true life full of passion, love, and suffering and decay. The image of the dead Christ however is still a means of aesthetics, but it is redefined by the thinkers in a way that goes beyond its purely artistic con-

75. Ibid., p. 58.

76. Martin Halliwell, Images of Idiocy: The Idiot Figure in Modern Fiction and Film (Aldershot: Ashgate, 2004) pp. 83-84.

77. Dostoevsky, The Idiot, p. 34. 
fines. It is a dynamic and forceful image that communicates and interacts with the viewer-reader.

In this essay I intended to show that the engagements of Kierkegaard and Dostoevsky with the image of the dead Christ aim at redefining the common view of Christianity. By undertaking this task, the thinkers introduce challenging models of the Christian ideal. Kierkegaard's guerilla-martyr and Dostoevsky's Christian-idiot impel their "interlocutors" to their own deconstruction. Subsequently, these models of the ideal Christian open the sphere of possibility for an individual to embark on "growing to be" a genuine Christian, a process that consists in perpetually becoming a Christian in following Christ (for Kierkegaard) and in approaching one's notion of Christianity through the inescapable uncertainty of death (for Dostoevsky).

\section{Australian Catholic University (Melbourne)}

